University of Nebraska - Lincoln

DigitalCommons@University of Nebraska - Lincoln

Biological Systems Engineering: Papers and Publications

Biological Systems Engineering

$12-1992$

\title{
Sediment Delivery on Rill and Interrill Areas
}

John E. Gilley

University of Nebraska-Lincoln, john.gilley@ars.usda.gov

D. C. Kincaid

United Staes Department of Agriculture

W. J. Elliot

Ohio State University

J. M. Laflen

Purdue University

Follow this and additional works at: https://digitalcommons.unl.edu/biosysengfacpub

Part of the Biological Engineering Commons

Gilley, John E.; Kincaid, D. C.; Elliot, W. J.; and Laflen, J. M., "Sediment Delivery on Rill and Interrill Areas" (1992). Biological Systems Engineering: Papers and Publications. 127.

https://digitalcommons.unl.edu/biosysengfacpub/127

This Article is brought to you for free and open access by the Biological Systems Engineering at DigitalCommons@University of Nebraska - Lincoln. It has been accepted for inclusion in Biological Systems Engineering: Papers and Publications by an authorized administrator of DigitalCommons@University of Nebraska Lincoln. 


\title{
Sediment delivery on rill and interrill areas
}

\author{
J.E. Gilley ${ }^{\mathrm{a}}$, D.C. Kincaid ${ }^{\mathrm{b}}$, W.J. Elliot ${ }^{\mathrm{c}}$ and J.M. Laflen ${ }^{\mathrm{d}}$ \\ ${ }^{2}$ USDA-ARS, University of Nebraska, Lincoln, NE 68583, USA \\ ${ }^{\mathrm{b}}$ USD A-ARS, Kimherly, ID 83341 , USA \\ "Agricultural Engineering Department, Ohio State University, Columhus, OH 43210, USA \\ "USDA-ARS, Purdue University, West Lafavete, IN 47907, USA \\ (Received 16 October 1991; revision accepted 7 Anril 19921
}

\begin{abstract}
Gilley, J.E., Kincaid, D.C.. Elliot, W.J. and Laflen, J.M., 1992. Sediment delivery on rill and interrill areas. J. Hydrol., 140: 313-341.

Equations which relate sediment delivery to a power function of flow rate and slope gradient were evaluated in this study. The data used to parameterize the equations were obtained from sites where crop residues had been removed, and moldboard plowing and disking had occurred. Measurements of sediment delivery resulting from simulated rainfall were obtained from preformed rills and interrill areas. The equations provided reliable sediment delivery estimates for selected soils located throughout the United States. To use the sediment delivery equations, soil-related parameter values must be identified. Multiple regression analyses were performed to relate parameter values used in the equations to selected soil properties. Equations were also developed for estimating rill sediment delivery under rainfall conditions from rill soil loss and discharge data collected without the addition of rainfall. The equations identified in this study, and appropriate soils information, ean be used to predict sediment delivery on both rill and interrill areas.
\end{abstract}

\section{INTRODUCTION}

The important mechanisms affecting soil erosion have been identified. These factors are usually complex and difficult to represent mathematically. As a result, empirical equations are often used to estimate the influence of significant soil detachment and transport factors on the erosion process.

Well-established procedures can be used to predict sediment transport in streams and rivers. Lane (1955) presented a general expression for analyzing river response to stream morphology. The product of sediment discharge and particle diameter was found to be related to flow rate and slope of the stream. A variety of commonly used sediment transport theories and their application

Correspondence to: J.E. Gilley, USDA-ARS, University of Nebraska, Lincoln, NE 68583. USA. 
in stream and river systems were described by Simons and Senturk (1976). Transport concepts for both bed load and suspended load were presented.

Alonso et al. (1981) examined several transport formulas useful in hydrologic modeling. The suitability of selected equations in estimating sediment transport for a wide range of variables usually encountered in agricultural watersheds was evaluated. Kirkby (1978) and Quansah (1985) proposed power functions of flow rate to describe rill erosion.

A general sediment transport relationship for overland flow was identified by Julien and Simons (1985) using dimensional analysis. The equation related sediment discharge to a power function of flow rate and slope. Power functions of flow rate and slope have also been used to estimate interrill sediment delivery (Guy et al., 1987) and erosion from furrow irrigation (Kemper et al., 1985). The objectives of this investigation were to: (1) test the suitability of a power function of flow rate and slope for use in estimating sediment delivery on rill and interrill areas; (2) relate regression coefficients used in the rill and interrill erosion equations to selected soil properties.

\section{SEDIMENT DELIVERY MEASUREMENT PROCEDURES}

Sediment delivery was measured by Elliot et al. (1989) on soils located throughout the United States. The locations, slopes and particle size analyses of the soils are presented in Table 1. The soils were selected to cover a broad range of physical, chemical, mineralogical and biological properties. These properties resulted from diverse soil-forming factors acting through time, including climate, parent material, vegetation, biological activity and topography. Each of the soils is considered to be of regional or national importance.

The study areas were located on uniform slopes having homogeneous soil characteristics. Either corn or small grains had been planted the previous year. All surface residue was first removed, and the area was then moldboard plowed 3-12 months before the tests were conducted. After plowing, sites were disked lightly and maintained free of vegetation either by tillage or application of herbicide.

Soil samples for site characterization were obtained and analyzed using standard procedures (Soil Survey Staff, 1984). Samples were collected at a central location and at several satellite points as is typical in a standard soil survey. The following properties were measured at each site: cation exchange capacity; coefficient of linear extensibility; dithionite-citrate extractable aluminum and iron content; exchangeable calcium, magnesium, potassium and sodium; percentage of sample consisting of clay, organic carbon, sand. silt, very fine sand and water-dispersible clay; and soil water retained by a soil 
TABLE 1

Location, slope and particle size analyses of selected soils

\begin{tabular}{|c|c|c|c|c|c|c|c|c|}
\hline \multirow[t]{3}{*}{ Soil } & \multicolumn{2}{|l|}{ Location } & \multirow{3}{*}{$\begin{array}{l}\text { Average rill } \\
\text { slope }(\%)\end{array}$} & \multirow{2}{*}{\multicolumn{2}{|c|}{$\begin{array}{l}\text { Average interrill } \\
\text { slope }(\%)\end{array}$}} & \multirow{2}{*}{\multicolumn{3}{|c|}{$\begin{array}{l}\text { Particle size } \\
\text { analysis } \\
\text { (\% by_weight) }\end{array}$}} \\
\hline & \multirow[t]{2}{*}{ County } & \multirow[t]{2}{*}{ State } & & & & & & \\
\hline & & & & Non-ridged & Ridged & Sand & Silt & Clay \\
\hline Academy & Fresno & California & 4.5 & 4.2 & 49.5 & 62.7 & 29.1 & 8.2 \\
\hline Amarillo & Howard & Texas & 3.6 & 3.5 & 44.5 & 85.0 & 7.7 & 7.3 \\
\hline Barnes-MN & Stevens & Minnesota & 8.3 & 8.0 & 56.7 & 48.6 & 34.4 & 17.0 \\
\hline Barnes-ND & Sheridan & N. Dakota & 5.8 & 5.9 & 48.6 & 39.5 & 36.0 & 24.5 \\
\hline Caribou & Aroostook & Maine & 8.8 & & 51.0 & 47.0 & 40.3 & 12.7 \\
\hline Cecil & Oconec & Georgia & 4.5 & & 51.0 & 64.6 & 15.6 & 19.8 \\
\hline Collamer & Tompkins & New York & 8.7 & & 51.0 & 7.0 & 78.0 & 15.0 \\
\hline Frederick & Washington & Maryland & 12.8 & & 51.0 & 25.1 & 58.3 & 16.6 \\
\hline Gaston & Rown & N. Carolina & 6.4 & & 51.0 & 35.5 & 25.4 & 39.1 \\
\hline Grenada & Panola & Mississippi & 8.7 & & 51.0 & 2.0 & 77.8 & 20.2 \\
\hline Heiden & Falls & Texas & 3.9 & 4.1 & 46.6 & 8.6 & 38.3 & 53.1 \\
\hline Hersh & Valley & Nebraska & 6.6 & 6.6 & 58.9 & 74.4 & 15.9 & 9.7 \\
\hline Hiwassec & Oconec & Gcorgia & 4.0 & & 51.0 & 63.7 & 21.6 & 14.7 \\
\hline Lcwisburg & Whitley & Indiana & 7.5 & & 51.0 & 38.5 & 32.2 & 29.3 \\
\hline Los Banos & Merced & California & 4.0 & & 57.0 & 16.0 & 41.0 & 43.0 \\
\hline Manor & Howard & Maryland & 8.6 & & 51.0 & 43.6 & 30.7 & 25.7 \\
\hline Mexico & Boonc & Missouri & 3.9 & & 51.0 & 5.3 & 68.7 & 26.0 \\
\hline Miami & Montgomery & Indiana & 5.8 & & 51.0 & 4.2 & 72.7 & 23.1 \\
\hline Miamian & 'Montgomery & Ohio & 8.9 & & 51.0 & 30.6 & 44.1 & 25.3 \\
\hline Nansene & Whitman & Washington & 6.1 & 7.1 & 60.0 & 20.1 & 68.8 & 11.1 \\
\hline Opequon & Allegany & Maryland & 12.0 & & 51.0 & 37.7 & 31.2 & 31.1 \\
\hline Palouse & Whitman & Washington & 6.5 & 6.3 & 61.5 & 9.8 & 70.1 & 20.1 \\
\hline Pierre & Jackson & S. Dakota & 6.6 & & 57.7 & 9.6 & 40.9 & 49.5 \\
\hline Portncul & Twin Falls & Idaho & 5.6 & 5.8 & 4.3 .7 & 21.5 & 67.4 & 11.1 \\
\hline Sharpsburg & Lancaster & Nebraska & 5.7 & 5.6 & 57.0 & 4.8 & 55.4 & 39.8 \\
\hline Sverdrup & Grant & Minnesota & 4.2 & 4. 1 & 56.8 & 75.3 & 16.8 & 7.9 \\
\hline Tifton & Worth & Georgia & 4.6 & & 51.0 & 86.4 & 10.8 & 2.8 \\
\hline Whitney & Fresno & California & 7.4 & 7.2 & 38.6 & 71.0 & 21.8 & 7.2 \\
\hline Williams & Sheridan & N. Dakota & 5.1 & 5.0 & 48.4 & 41.6 & 32.4 & 26.0 \\
\hline Woodward & Harper & Oklahoma & 7.1 & 7.4 & 45.1 & 43.7 & 42.4 & 13.9 \\
\hline Zahl & Roosevelt & Montana & 7.6 & 7.6 & 48.5 & 46.3 & 29.7 & 24.0 \\
\hline
\end{tabular}

sample at 0.3 and 1.5 MPa tension. Mean, minimum and maximum values of selected soil properties at the study sites are shown in Table 2.

A plot diagram of a typical rainfall simulation site is shown in Fig. 1. The study areas were disked immediately preceding testing. Six rills, $0.46 \mathrm{~m}$ across 


\section{TABLE 2}

Mean, minimum and maximum values of selected soil properties at the study sites

\begin{tabular}{|c|c|c|c|}
\hline Soil property & Mean & Minimum & Maximum \\
\hline Aluminum $(\%)$ & 0.15 & 0.03 & 0.50 \\
\hline Calcium ( $\mathrm{cmol} \mathrm{kg}^{-1}$ ) & 9.0 & 0.0 & 33 \\
\hline Cation exchange capacity (cmol kg ${ }^{\text {') }}$ & 15 & 1.7 & 39 \\
\hline Clay $(\%)$ & 21 & 2.8 & 53 \\
\hline Cocfficient of linear extensibility $\left(\mathrm{cm} \mathrm{cm}^{\prime}\right)$ & 0.03 & 0.00 & 0.10 \\
\hline Iron $(\%)$ & 1.2 & 0.20 & 4.5 \\
\hline Magnesium (cmolkg $\left.{ }^{1}\right)$ & 2.7 & 0.10 & 9.2 \\
\hline Organic carbon $(\%)$ & 1.2 & 0.16 & 3.3 \\
\hline Potassium (cmolkg $\left.{ }^{\prime}\right)$ & 0.65 & 0.10 & 2.5 \\
\hline Sand $(\%)$ & 40 & 2.0 & 91 \\
\hline Silt $(\%)$ & 39 & 5.5 & 78 \\
\hline Sodium (cmolkg ') & 0.09 & 0.00 & 0.60 \\
\hline Soil water content at $0.3 \mathrm{MPa}(\%)$ & $2 \mathrm{I}$ & 4.9 & 34 \\
\hline Soil water content at $1.5 \mathrm{MPa}(\%)$ & 9.6 & 1.1 & 19 \\
\hline Very fine sand $(\%)$ & 12 & 1.1 & 44 \\
\hline Water-dispersible clay $(\%)$ & 8.3 & 1.1 & 25 \\
\hline
\end{tabular}

the slope by $9.0 \mathrm{~m}$ long, were formed using a ridging tool mounted on a small tractor. A sheet metal border was placed at the top of each rill and a runoff collection device was located at the bottom. Details and dimensions of the rill plots are presented in Fig. 2.

Each of the sites also contained six interrill erosion plots. These $0.50 \mathrm{~m}$ wide by $0.75 \mathrm{~m}$ long plots had relatively steep sides sloping toward a central collection trough (ridged plots). At 15 of the locations, two additional interrill plots with slopes similar to the existing topography were also established (non-ridged plots). Average slopes for both the ridged and non-ridged plots are presented in Table 1.

A portable rainfall simulator designed by Swanson (1965) was used to apply rainfall at an intensity of approximately $62 \mathrm{~mm} \mathrm{~h}{ }^{~}$. Erosion data collection was divided into three periods: (1) rainfall only until equilibrium of rill flow occurred; (2) rainfall plus flow addition in increments at the top of each rill; (3) flow addition at the top of each rill without rainfall.

Runoff samples were obtained from the interrill plots only during the initial simulation period. Interrill sample collection intervals ranged from 5 to 10 min. Rill runoff observations were made every 5 min after the beginning of runoff until equilibrium conditions occurred. Rill and interrill flow rates obtained during the experimental tests are shown in Table 3.

During the second simulation period, rainfall was resumed and rill outflow 


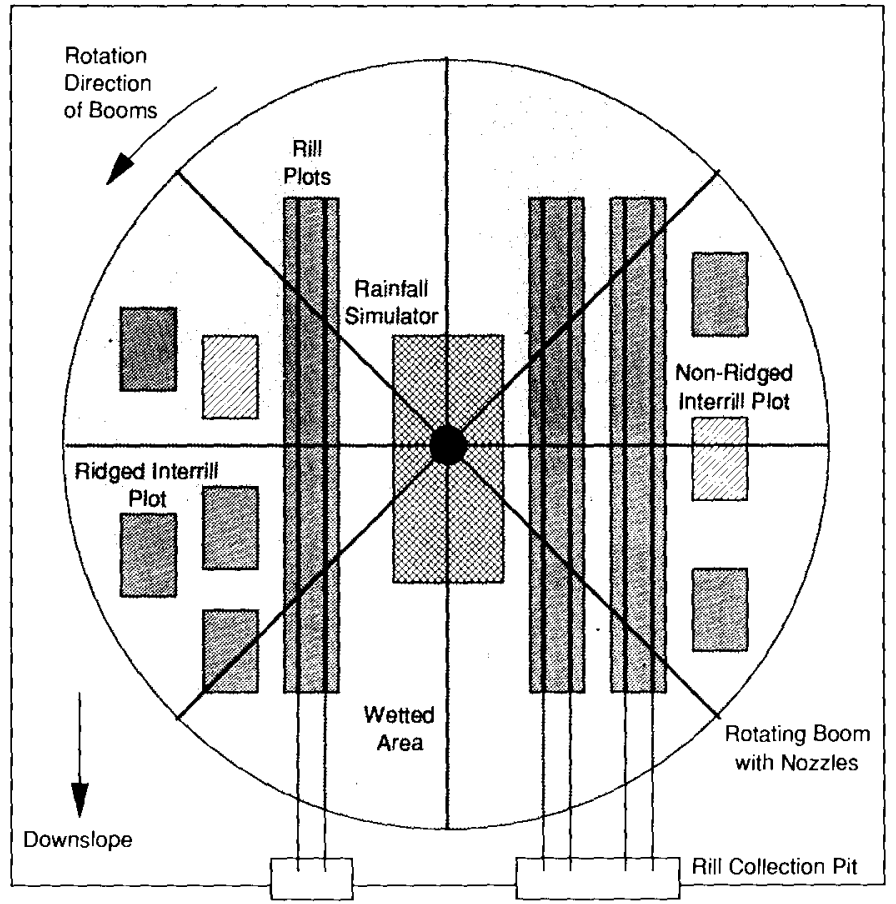

Fig. 1. Plot diagram of a rainfall simulation site.

was measured to identify steady-state runoff conditions. Once equilibrium was established, flow was added to the top of each rill at rates of $7,14,21,28$ and $351 \mathrm{~min}$ '. For each inflow increment rate, two (replicate) runoff samples were obtained from each rill for determination of discharge rate and sediment concentration. Each rill was then handled as a separate replication in the statistical analyses.

Inflow was added without rainfall during the third period. Inflow rates, runoff measurement procedures and sediment sampling techniques were the same as those used during the second simulation period. Additional details concerning experimental procedures are given by Elliot et al. (1989).

\section{RILI. SEDIMENT DELIVERY WITH RAINFALL}

\section{Testing of sediment delivery equation}

Figure 3 shows rill sediment delivery rates with rainfall vs. flow rates for a Nansene soil. The results presented for the Nansene soil are also representative of the other experimental sites. Kirkby (1978) and Quansah (1985) reported a similar increase in sediment delivery rate with flow rate. 

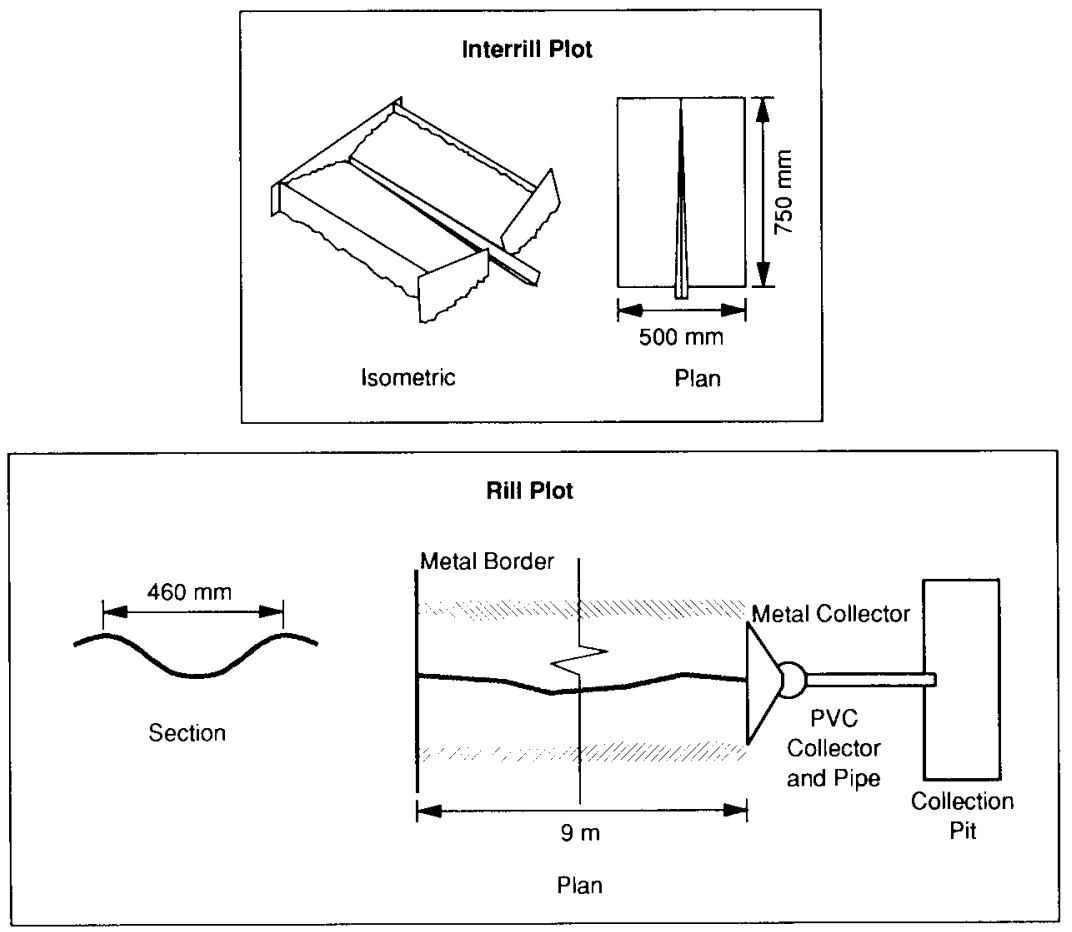

Fig. 2. Details and dimensions of the interrill and rill plots.

It can be seen from Fig. 3 that the experimental data fall into distinct groups. These groups correspond to separate inflow increments. Substantial variations in sediment delivery were sometimes found for a given flow rate. These differences were usually larger at the higher flow rates.

Kemper et al. (1985) suggested an equation of the following form for estimating sediment delivery rate from an irrigation furrow:

sediment delivery rate $=a$ flow rate slope $^{1.5 h}$

where $a$ and $b$ are regression coefficients. The regression coefficient $b$ in eqn. (1) was identified for the with rainfall condition for each of the soils, and a mean value of 1.28 (standard deviation equals 0.363 ) was then determined. For rill sediment delivery rate and flow rate given in grams per second and liters per minute, respectively, and slope given as a fraction, the following equation was obtained

rill sediment delivery rate with rainfall $=c$ flow rate slope $^{1.92}$

The effects of slope length on rill sediment delivery rate are incorporated into eqn. (2) through the flow rate variable. As slope length increases, flow rate 
TABLE 3

Rill and interrill flow rates obtained during the experimental tests

\begin{tabular}{|c|c|c|c|c|c|c|c|c|}
\hline \multirow[t]{3}{*}{ Soil } & \multicolumn{4}{|c|}{ Rill flow rates ( $1 \mathrm{~min}{ }^{\prime}$ ) } & \multicolumn{4}{|c|}{ Interrill llow rates $\left(\mathrm{mm} \mathrm{h}^{\prime}\right)$} \\
\hline & \multicolumn{2}{|c|}{ With rainfall } & \multicolumn{2}{|c|}{ Without rainfall } & \multicolumn{2}{|c|}{ Ridged areas } & \multicolumn{2}{|c|}{ Non-ridged areas } \\
\hline & Min. & Max. & Min. & Max. & Min. & Max. & Min. & $\operatorname{Max}$ \\
\hline Academy & 3.2 & 41.7 & 4.6 & 39.6 & 7.5 & 52.2 & 0.4 & 56.3 \\
\hline Amarillo & 8.9 & 48.7 & 5.5 & 42.8 & 0.7 & 51.9 & 1.1 & 54.4 \\
\hline Barnes-MN & 3.4 & 37.6 & 4.8 & 36.8 & 3.9 & 60.8 & 1.6 & 57.0 \\
\hline Barnes-ND & 2.8 & 47.2 & 2.5 & 41.8 & 4.7 & 52.3 & 2.3 & 54.0 \\
\hline Caribou & 3.4 & 44.5 & 6.1 & 39.3 & 35.0 & 64.5 & & \\
\hline Cecil & 11.0 & 43.4 & 6.0 & 37.4 & 27.0 & 62.0 & & \\
\hline Collamer & 3.2 & 46.5 & 7.1 & 48.1 & 39.1 & 59.0 & & \\
\hline Frederick & 3.2 & 46.8 & 6.0 & 41.4 & 27.1 & 65.4 & & \\
\hline Gaston & 3.2 & 47.3 & 5.3 & 39.9 & 30.3 & 77.7 & & \\
\hline Grenada & 3.0 & 48.8 & 5.7 & 48.8 & 5.3 & 59.7 & & \\
\hline Heiden & 2.8 & 42.9 & 4.4 & 39.3 & 2.1 & 70.9 & 2.2 & 67.2 \\
\hline Hersh & 2.4 & 54.3 & 5.8 & 43.1 & 4.7 & 61.4 & 2.6 & 61.6 \\
\hline Hiwassec & 3.4 & 39.1 & 5.0 & 36.2 & 40.6 & 64.8 & & \\
\hline Lewisburg & 3.2 & 42.4 & 6.1 & 39.8 & 21.8 & 56.7 & & \\
\hline Los Banos & 2.1 & 31.3 & 4.9 & 29.7 & 3.2 & 57.7 & & \\
\hline Manor & 3.7 & 44.5 & 5.6 & 42.8 & 18.8 & 60.6 & & \\
\hline Mexico & 3.4 & 45.4 & 5.6 & 38.6 & 1.0 & 54.7 & & \\
\hline Miami & 2.9 & 43.0 & 5.2 & 42.5 & 13.8 & 57.9 & & \\
\hline Miamian & 3.3 & 44.0 & 7.9 & 42.6 & 13.5 & 57.3 & & \\
\hline Nansene & 3.2 & 52.7 & 6.4 & 38.0 & 5.0 & 71.2 & 0.7 & 45.3 \\
\hline Opeyuon & 3.6 & 41.0 & 3.9 & 41.3 & 45.3 & 75.6 & & \\
\hline Palousc & 3.3 & 43.9 & 5.6 & 38.6 & 4.4 & 56.4 & 1.8 & 48.9 \\
\hline Picre & 3.1 & 39.8 & 3.7 & 37.8 & 4.4 & 58.8 & & \\
\hline Portneuf & 2.6 & $4 ! .7$ & 4.5 & 43.8 & 2.2 & 38.7 & 2.1 & 34.9 \\
\hline Sharpsburg & 3.8 & 40.9 & 3.4 & 38.4 & 5.4 & 57.5 & 2.9 & 59.7 \\
\hline Sverdrup & 1.8 & 37.4 & 4.3 & 35.4 & 3.8 & 41.9 & 1.8 & 43.3 \\
\hline Tifton & 9.1 & 42.0 & 4.6 & 39.5 & 9.8 & 35.6 & & \\
\hline Whitney & 2.8 & 38.9 & 4.7 & 37.9 & 4.1 & 63.8 & 2.0 & 50.7 \\
\hline Williams & 2.9 & 47.6 & 1.9 & 44.4 & 3.9 & 59.0 & 2.4 & 44.7 \\
\hline Woodward & 3.0 & 39.8 & 5.7 & 42.1 & 3.3 & 52.1 & 1.7 & 55.2 \\
\hline Zahl & 2.7 & 43.9 & 4.5 & 41.1 & 4.6 & 56.7 & 2.2 & 55.5 \\
\hline
\end{tabular}

becomes larger causing increased rill sediment delivery rates. Since eqn. (2) provides estimates of rill sediment delivery rates corresponding to a particular flow rate, it can be used directly for steady-state runoff conditions. To determine total sediment delivery over an entire runoff event, eqn. (2) should be integrated with time.

Using eqn. (2), additional analyses were performed to determine the appropriate regression coefficient $c$ for each of the individual soils. Non-linear 


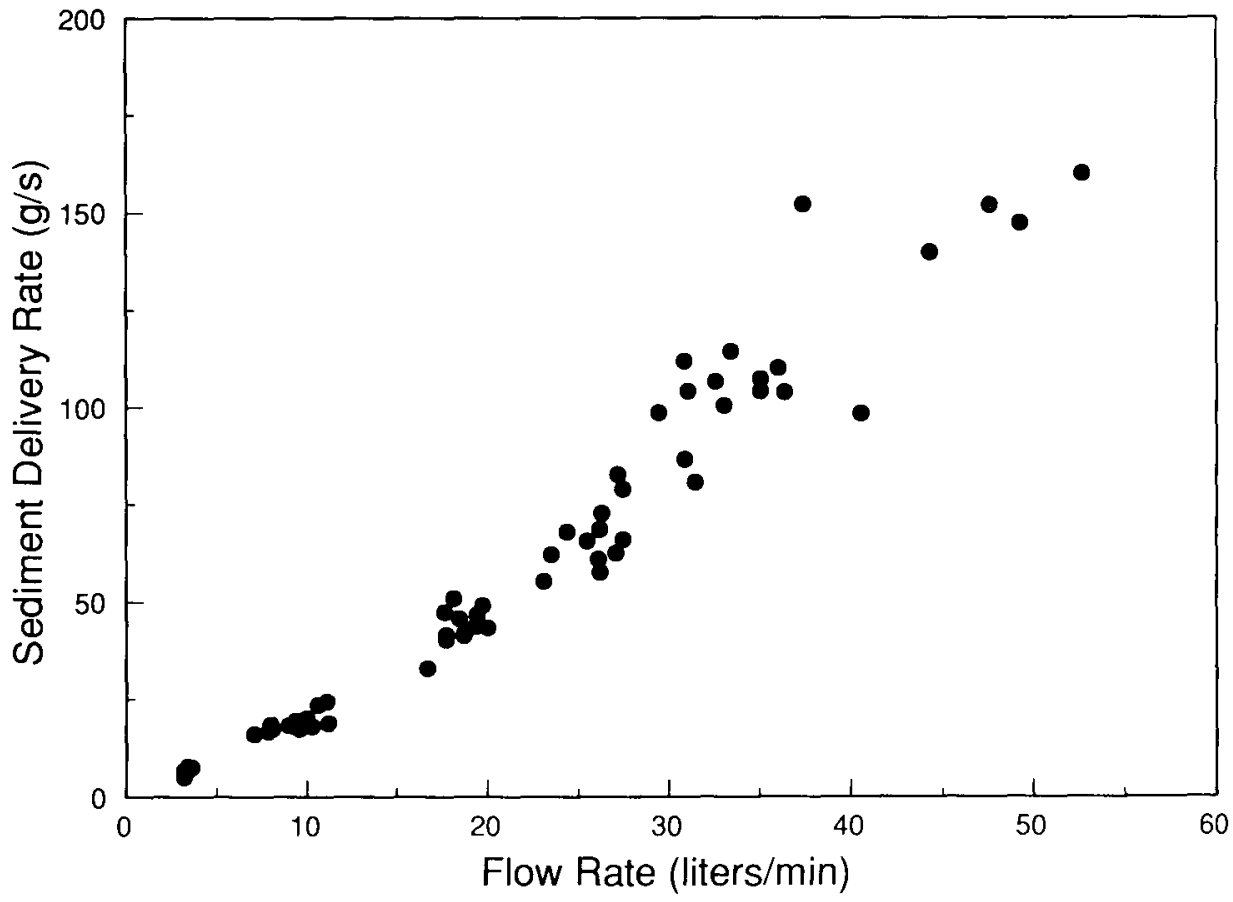

Fig. 3. Rill sediment delivery rates with rainfall vs. flow rates for a Nansene soil.

regression procedures were first used to identify appropriate regression coefficients. Rill sediment delivery rate was then estimated using the regression coefficients. Finally, appropriate $r^{2}$ values were obtained from a simple linear regression of predicted vs. measured rill sediment delivery rates.

Results of the regression analyses are shown in Table 4 . The value of c was found to vary from 24.2 for the Opequon soil to 386 for the Amarillo soil. The statistical analyses suggest that flow rate and slope gradient can be used to estimate rill sediment delivery. Predicted vs. measured rill sediment delivery rates with rainfall for the Nansene soil are shown in Fig. 4. In general, close agreement was found between predicted and measured values.

Estimates of rill sediment delivery rates were obtained from eqn. (2) for sites located throughout the United States. This relation is relatively easy to use since only flow rate and slope gradient are included as independent variables. However, information on the regression coefficient $c$ is required for use of eqn. (2).

Parameter value identification

Step-wise multiple regression analyses were performed to relate values of c 


\section{TABLE 4}

Coefficients used to estimate rill sediment delivery rate with rainfall given flow rate and slope gradient

Soil

Regression coefficient

$\left(c^{\mathrm{a}}\right)$
Coefficient of determination $\left(r^{2}\right)$

Magnesium $\leqslant 2.0$ cmolkg

Academy

Amarillo

Caribou

Cecil

Collamer

Frederick

Gaston

Grenada

Heiden

Hersh

Hiwasee

Manor

Miami

Opequon

Tifton

Whitney

Woodward
97.6

386

45.8

46.6

97.3

47.0

63.8

68.2

159

154

147

51.4

115

24.2

59.3

144

303
0.691

0.819

0.852

0.813

0.858

0.851

0.784

0.766

0.644

0.864

0.734

0.957

0.829

0.838

0.637

0.901

0.859

Magnesium $>2.0 \mathrm{cmolkg}$

Barnes-MN

0.788

Barnes-ND

44.1

0.764

L.ewishurg

55.5

0.733

Los Banos

29.9

0.680

Mexico

94.1

0.690

Miamian

80.7

0.827

Nansene

216

0.771

Palouse

98.5

0.919

Pierre

60.2

0.642

Portneuf

129)

Sharpsburg

60.1

0.889

Sverdrup

127

Williams

59.9

0.821

0.700

Zahl

109

0.749

0.757

"Regression coefficient $c$ is used in the equation: rill sediment delivery rate with rainfall $=c$ flow rate ${ }^{1.2 x}$ slope $e^{192}$, where rill sediment delivery rate and flow rate are in grams per second and liters per minute, respectively, and slope is given as a fraction. 


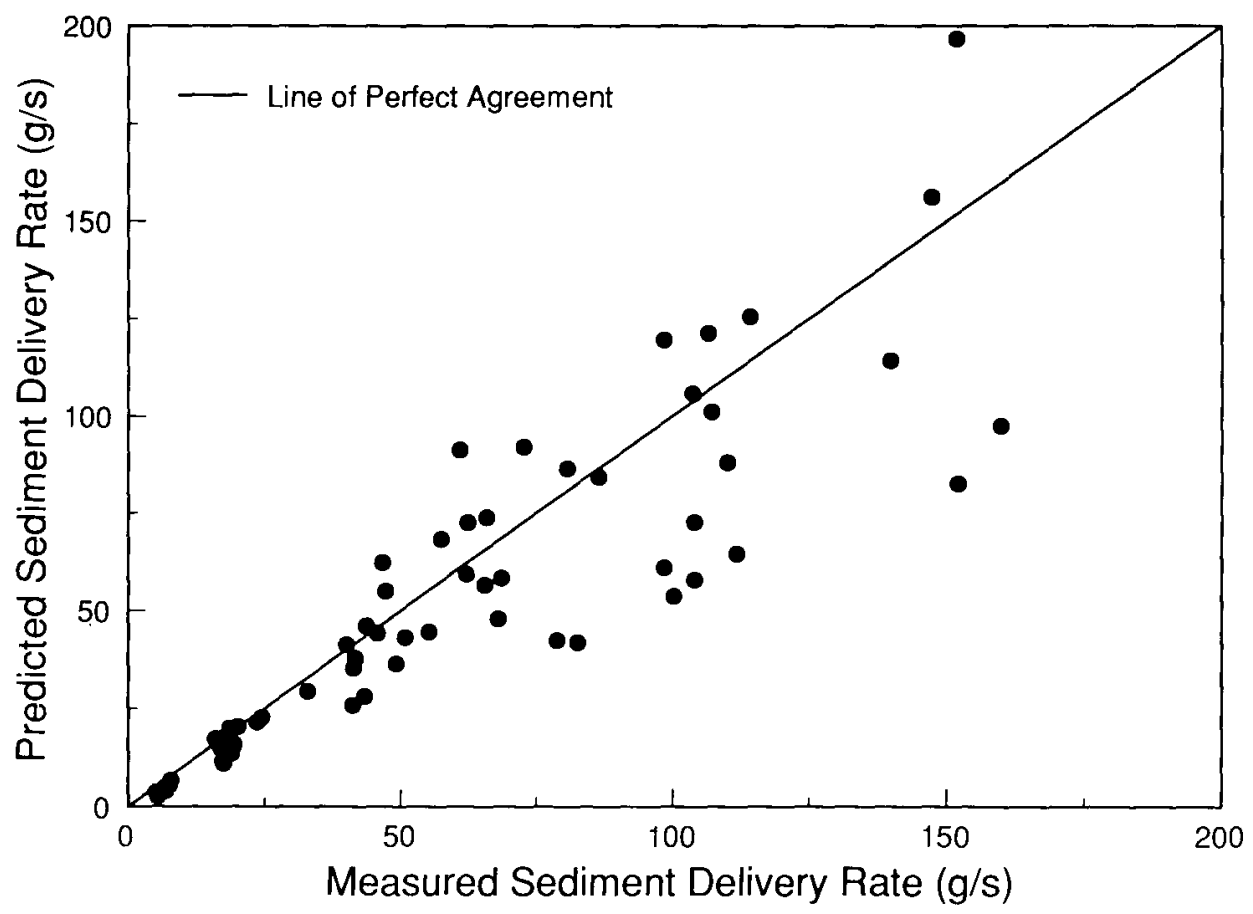

fïg. 4. Predicted vs. measured rill sediment delivery rates with rainfall for a Nansene soil.

presented in Table 4 to soil propertics shown in Table 2. Statistical analyses suggested that $c$ was significantly correlated to exchangeable magnesium. For soils with exchangeable magnesium less than or equal to $2.0 \mathrm{cmol} \mathrm{kg}$ '

$$
\begin{aligned}
c= & -11.9(\text { calcium })-117 \text { (organic carbon) } \\
& +8.10(\text { soil water content at } 0.3 \mathrm{MPa})+999(\text { sodium }) \\
& +6.95 \text { (very fine sand) }-14.8
\end{aligned}
$$

where calcium and sodium are in centimol per kilogram, and organic carbon, soil water content at $0.3 \mathrm{MPa}$, and very fine sand are given as percentages. All the regression coefficients shown in eqn. (3) were significantly different from 0 at the $95 \%$ confidence level. For exchangeable magnesium greater than $2.0 \mathrm{cmol} \mathrm{kg}{ }^{1}$

$$
\begin{aligned}
c= & -1554.3(\text { clay })+80.625(\text { potassium })-1556.0 \text { (sand) }-1555.7 \text { (silt) } \\
& -17.977 \text { (soil water content at } 1.5 \mathrm{MPa})+155,780
\end{aligned}
$$




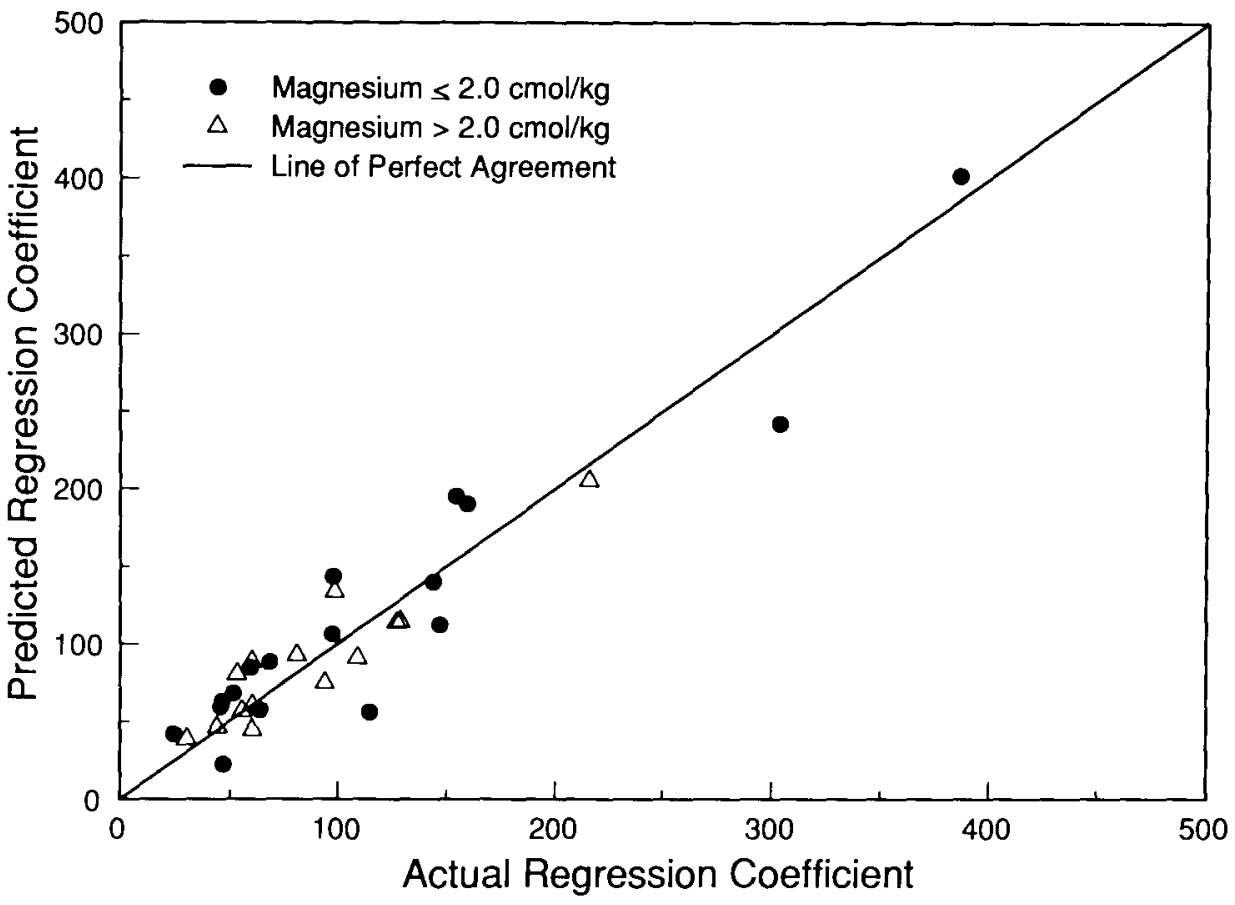

Fig. 5. Predicted vs. actual regression coefficients for estimating rill sediment delivery rates with rainfall.

where clay, sand, silt and soil water content at $1.5 \mathrm{MPa}$ are given as percentages, and potassium is in centimol per kilogram. All the regression coefficients shown in eqn. (4) were significantly different from 0 at the $90 \%$ confidence level.

Values of $($ were calculated for each of the experimental soils using soil survey data and eqns. (3) and (4). Results of the analyses are shown in Fig. 5 . It can be seen from Fig. 5 that predicted and actual values of c were similar.

Linear regression analyses were employed to compare predicted and actual values of $c$. Results of the statistical analyses are shown in Table 5 . Coefficient of determination values of 0.893 and 0.851 were found for eqns. (3) and (4), respectively.

The students $t$ test was used to evaluate the hypotheses that the regression coefficients shown in Table 5 for the with rainfall condition equal 1 and that the intercepts equal 0 at the $95 \%$ confidence level. The slopes were not significantly different from 1 nor were the intercepts significantly different from 0 . Thus, analysis of the experimental data suggests that eqns. (3) and (4) can be used to estimate the regression coefficient c used for rill sediment delivery. 
TABLE 5

Statistical analysis of predicted vs. actual regression coefficients used to estimate rill sediment delivery rate

\begin{tabular}{|c|c|c|c|c|c|c|}
\hline \multirow[t]{2}{*}{ Regression equation } & \multirow{2}{*}{$\begin{array}{l}\text { Coefficient of } \\
\text { determination } \\
\left(r^{2}\right)\end{array}$} & \multirow[t]{2}{*}{$F$} & \multicolumn{2}{|l|}{$\beta_{1}$} & \multicolumn{2}{|l|}{$\beta_{0}$} \\
\hline & & & Students & $\begin{array}{l}\text { Standard } \\
\text { error }\end{array}$ & Students $t$ & $\begin{array}{l}\text { Standard } \\
\text { error }\end{array}$ \\
\hline \multicolumn{7}{|l|}{ WITH RAINFALL } \\
\hline \multicolumn{7}{|l|}{ Magnesium $\leqslant 2.0 \mathrm{cmo} / \mathrm{kg}$} \\
\hline Predicted $=0.920$ actual +13.0 & 0.893 & 125 & -0.966 & 0.082 & 1.05 & 12.4 \\
\hline \multicolumn{7}{|l|}{ Magnesium $>2.0 \mathrm{molkg}$} \\
\hline Predicted $=0.847+14.8$ & 0.851 & 69 & -1.50 & 0.102 & 1.48 & 10.1 \\
\hline \multicolumn{7}{|l|}{ WITHOUT RAINFALL. } \\
\hline Predicted $=0.875$ actual +8.49 & 0.735 & 77 & -1.26 & 0.099 & 1.05 & 8.09 \\
\hline
\end{tabular}

\section{RILL. SEDIMENT DELIVERY WITHOUT RAINFALI}

\section{Testing of sediment delivery equation}

Rill sediment delivery rates without rainfall vs. flow rates for a Nansene soil are presented in Fig. 6. As was true for rainfall conditions, the experimental data can be seen to fall into distinct groups corresponding to separate inflow increments. Substantial variations in sediment delivery rates were found for a given flow rate, especially at the higher flow rates. Differences in sediment delivery rates at a particular flow rate appeared to be greater for the without rainfall run (Fig. 6) than for rainfall conditions (Fig. 3).

The regression coefficient $h$ in eqn. (1) was also identified for the without rainfall condition on each of the soils, and a mean value of 1.18 (standard deviation equals 0.287 ) was then determined. The following equation was obtained for rill sediment delivery rate and flow rate given in grams per second and liters per minute, respectively, and slope given as a fraction

rill sediment delivery rate without rainfall $=d$ flow rate slope $^{1.77}$

In contrast to the with rainfall situation, flow rates and sediment delivery rates would be expected to decrease with downslope distance for the without rainfall condition.

Additional analyses were performed to determine the appropriate regression coefficient $d$ for each of the individual soils. Regression coefficients were first identified using non-linear regression procedures. The regression coefficients were then used to estimate rill sediment delivery rates. Finally, a 


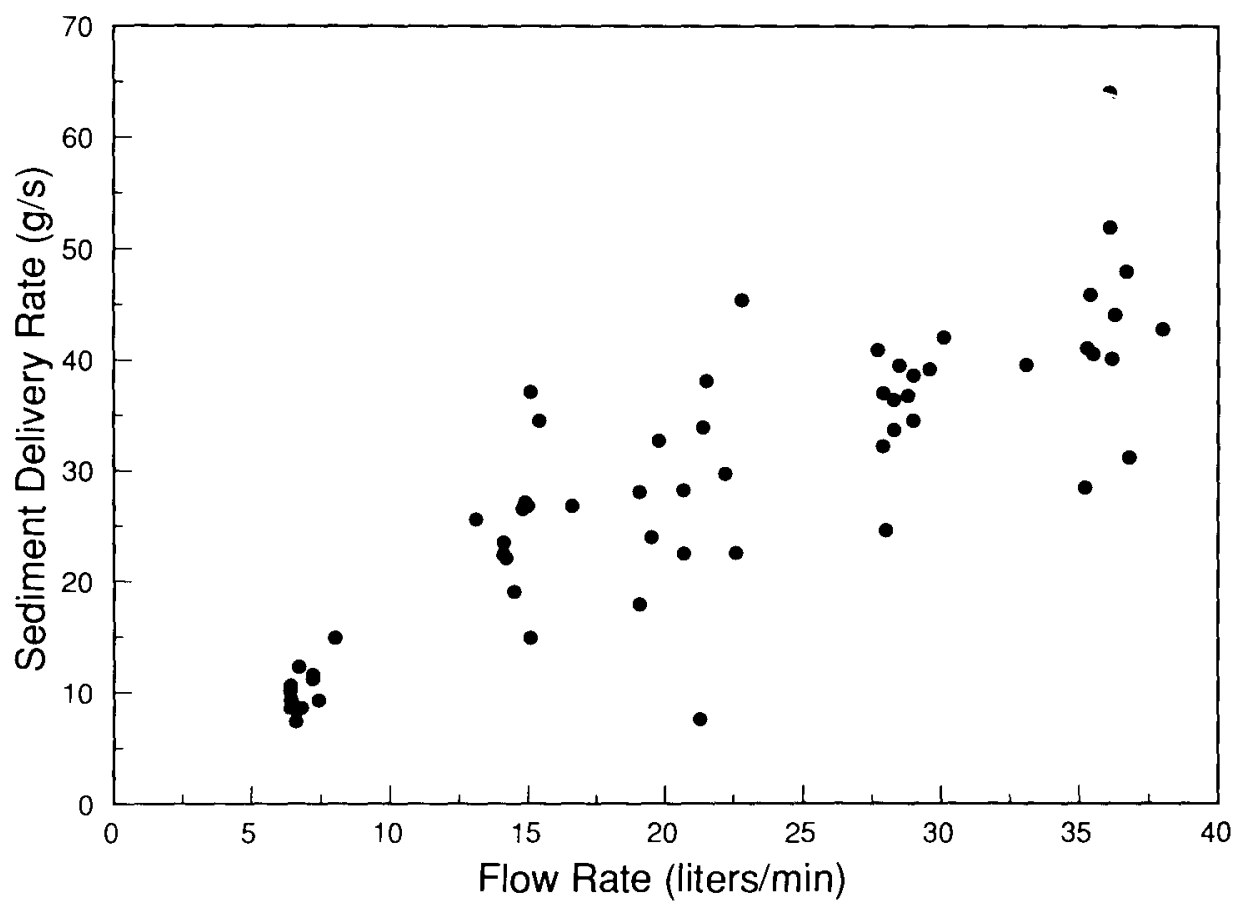

Fig. 6. Rill sediment delivery rates without rainlall vs. flow rates lor a Nansene soil.

simple linear regression of predicted vs. measured rill sediment delivery rates was used to obtain appropriate $r^{2}$ values.

Results of the regression analyses are shown in Table 6 . The value of $d$ was found to vary from 6.90 for the Los Banos soil to 220 for the Amarillo soil. Results of the statistical analyses suggest that flow rate and slope gradient can also be used to estimate rill sediment delivery without rainfall. Predicted vs. measured rill sediment delivery rates without rainfall for a Nansene soil are shown in Fig. 7. In general, close agreement was found between predicted and measured values.

\section{Parameter value identification}

Values of $d$ presented in Table 6 were related to soil properties shown in Table 2 using step-wise multiple regression analyses. The Los Banos soil with its relatively low regression coefficient was not included in the analyses. Statistical analyses yielded the following relation

$$
\begin{aligned}
d= & -123 \text { (aluminum) }-1.71 \text { (calcium) }-22.7 \text { (organic carbon) } \\
& -0.628(\text { silt })+345(\text { sodium })+134
\end{aligned}
$$


TABLE 6

Coefficients used to estimate rill sediment delivery rate without rainfall given flow rate and slope gradient

Soil

Regression coeflicient

$\left(d^{\mathrm{a}}\right)$

69.1

220

55.6

35.4

I2.9

58.7

69.1

19.7

47.6

51.9

104

116

Hersh

Hiwassec

Lewisburg

Los Banos

Manor

Mexico

Miami

Miamian

Nansene

Opequon

Palouse

Pierre

Portneuf

Sharpsburg

Sverdrup

Tifton

Whitncy

Williams

Woodward

Zahl
123

55.7

6.90

45.5

45.8

87.5

50.0

97.0

26.2

54.7

77.8

106

39.7

84.4

65.8

124

38.6

75.6

70.5
Coefficient of determination $\left(r^{2}\right)$

0.851

0.819

0.849

0.815

0.842

0.827

0.843

0.892

0.712

0.739

0.738

0.883

0.917

0.751

0.732

0.891

0.839

0.730

0.633

0.753

0.708

0.903

0.607

0.882

0.860

0.732

0.859

0.858

0.866

0.714

0.760

"Regression coefficient $d$ is used in the equation: rill sediment delivery rate without rainfall = d flow rate ${ }^{1.18}$ slope $^{1.77}$, where rill sediment delivery rate and flow rate are in grams per second and liters per minute, respectively, and slope is given as a fraction. 


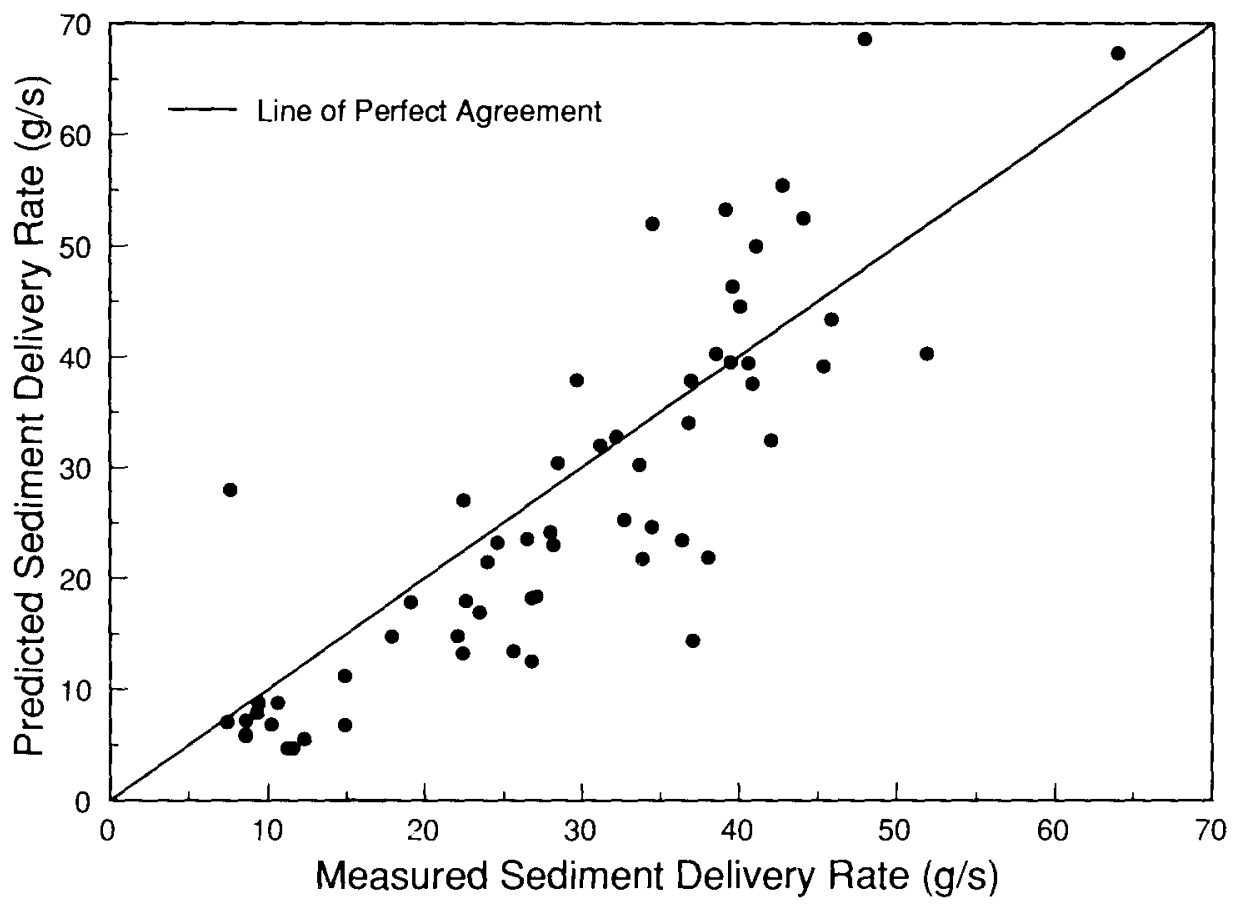

Fig. 7. Predicted vs. measured rill sediment delivery rates without rainlall for a Nansene soil.

where aluminum, organic carbon and silt are given as percentages, and calcium and sodium are in centimol per kilogram. All of the regression coefficients shown in eqn. (6) were significantly different from 0 at the $95 \%$ confidence level.

The soil survey data and eqn. (6) were used to calculate values of $d$ for each of the experimental soils. Results of the analyses are shown in Fig. 8. Predicted and actual values of $d$ presented in Fig. 8 can be seen to be similar.

Predicted and actual values of $d$ were also compared using linear regression analyses. Results of the statistical analyses are shown in Table 5. A coefficient of determination value of 0.735 was found for eqn. (6).

The hypotheses that the regression coefficient shown in Table 5 for the without rainfall condition equals 1 and the intercept equals 0 at the $95 \%$ confidence level were evaluated using the students $t$ test. The slope was not significantly different from 1 nor the intercept significantly different from 0 . Thus, analyses of the experimental data suggests that eqn. (6) can be used to estimate the regression coefficient $d$. 


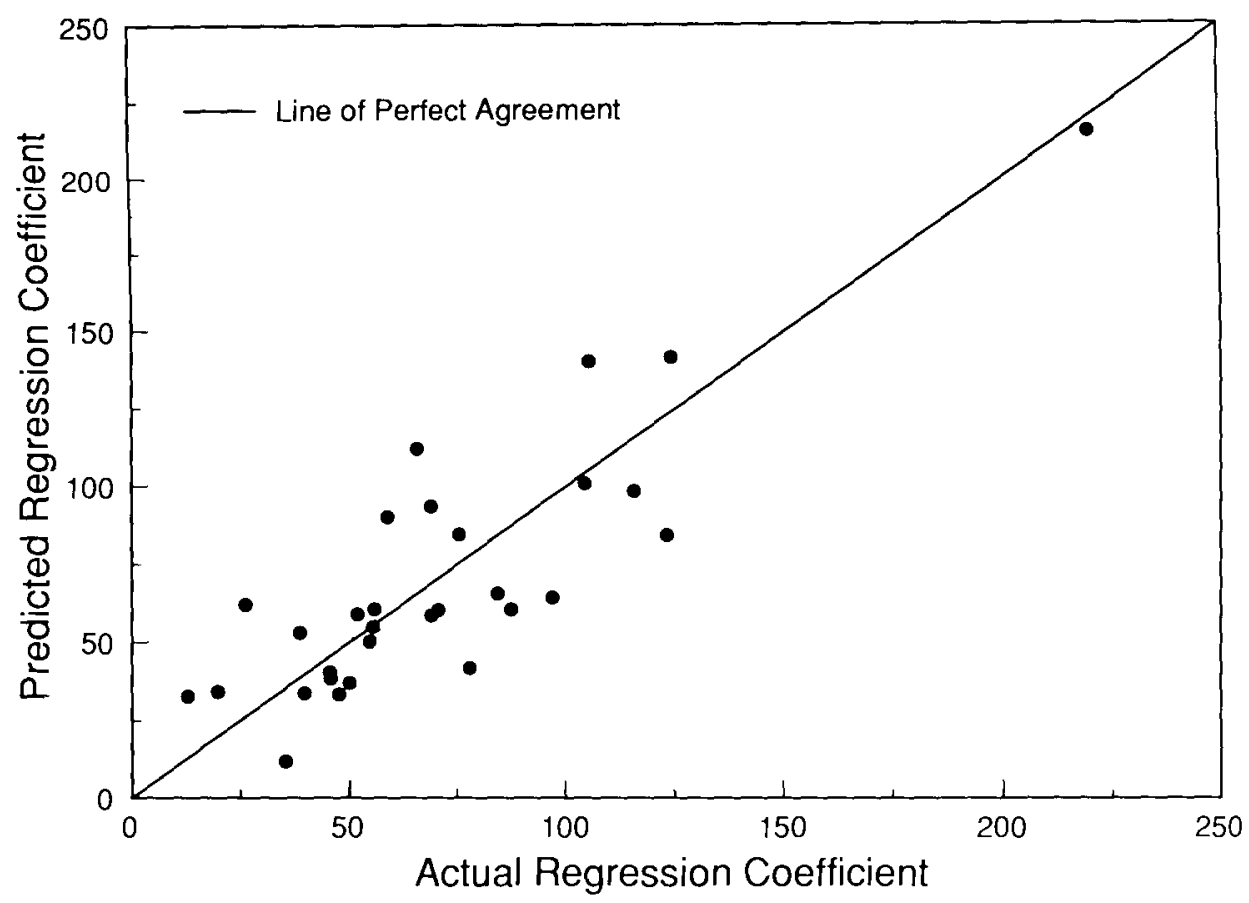

Fig. 8. Predicted vs. actual regression coefficients for estimating rill sedinent delivery rates without rainfitl.

Estimating sediment delivery from furrow irrigation

The experimental conditions existing when inflow was added to the rills without rainfall were similar to those found under furrow irrigation. Equation (1) was derived by Kemper et al. (1985) specifically for furrow irrigation. Thus, eqns. (5) and (6) could perhaps also be used to estimate sediment delivery from furrow irrigation.

Proper installation of equipment used to measure runoff and erosion can be difficult on relatively flat surfaces. In addition, accurate measurement of soil erodibility may be more easily accomplished on moderate slopes. As a result, the erosion data used to parameterize and test eqns. (5) and (6) were obtained from relatively uniform slopes with gradients varying from approximately 3.6 to $12.8 \%$. Furrow irrigation usually occurs on areas with much smaller slopes. Limited tests of eqn. (1) on relatively flat areas were performed by Kemper et al. (1985). Additional testing of eqns. (5) and (6) on surfaces with significantly lower slopes is needed. 
CORRECTION FACTORS FOR ESTIMATING RILL SEDIMENT DELIVERY

\section{Identifying correction factors}

Most rainfall simulators used under field conditions are relatively expensive. Several individuals are usually required to assist with simulation tests. If rill sediment delivery measurements could be made from preformed rills without the addition of rainfall, data collection requirements would be greatly simplified.

Correction factors were identified to allow estimates of sediment delivery from rills under rainfall conditions given rill sediment delivery measurements obtained without rainfall. By multiplying the regression coefficient $d$ obtained without rainfall (Table 6 ) by the appropriate correction factor, the regression coefficient c for use under rainfall situations (Table 4) can be identified. Equation (2) could then be used to estimate rill sediment delivery rate with rainfall. Regression coefficients shown in Table 6 were divided by corresponding values in Table 4 to obtain correction factors for each of the experimental sites. Correction factors shown in Table 7 ranged from 0.774 for the Pierre soil to 4.33 for the Los Banos soil.

\section{Parameter value identification}

The correction factors shown in Table 7 were related to soil properties presented in Table 2 using step-wise multiple regression analyses. The correction factors were found to be significantly correlated to the percentage of very fine sand. For soils with very fine sand $\leqslant 11.0 \%$

$e^{\prime}=1.88$ (aluminum) +0.0985 (clay) +1.02 (organic carbon)

- 0.315 (soil water content at 1.5 MPa)

-0.0375 (water-dispersible clay) + 1.11

where aluminum, clay, organic carbon, soil water content at $1.5 \mathrm{MPa}$, and water-dispersible clay are given as percentages. All the regression coefficients shown in eqn. (7) were significantly different from 0 at the $95 \%$ confidence level. For very fine sand $>11.0 \%$

$e=-0.0726$ (calcium) -0.871 (magnesium) -1.20 (organic carbon)

+0.849 (soil water content at $1.5 \mathrm{MPa})+0.213$

where calcium and magnesium are in centimol per kilogram, and organic carbon and soil water content at 1.5 MPa are given as percentages. All the regression coefficients shown in eqn. (8) were significantly different from 0 at the $95 \%$ confidence level. 


\section{TABLE 7}

Correction factors used to estimate sediment delivery rate from rills under rainfall conditions given rill sediment delivery without rainfall

\begin{tabular}{|c|c|}
\hline Soil & $\begin{array}{l}\text { Correction factor } \\
\left(e^{\mathrm{a}}\right)\end{array}$ \\
\hline \multicolumn{2}{|c|}{ Very fine sand $\leqslant 11.0 \%$} \\
\hline Cecil & 0.794 \\
\hline Collamer & 1.41 \\
\hline Frederick & 2.39 \\
\hline Gaston & 1.34 \\
\hline Grenada & 1.31 \\
\hline Heiden & 1.53 \\
\hline Hiwassec & 1.20 \\
\hline Lewisburg & 0.996 \\
\hline Manor & 1.13 \\
\hline Mexico & 2.06 \\
\hline Miami & 1.31 \\
\hline Miamian & 1.61 \\
\hline Opequon & 0.924 \\
\hline Palouse & 1.80 \\
\hline Pierre & 0.774 \\
\hline Sharpsburg & 1.51 \\
\hline Sverdrup & 1.51 \\
\hline Whitney & 1.16 \\
\hline \multicolumn{2}{|c|}{ Very fine sand $>11.0 \%$} \\
\hline Academy & 1.41 \\
\hline Amarillo & 1.75 \\
\hline Barnes-MN & 0.955 \\
\hline Barnes-ND & 1.25 \\
\hline Caribou & 3.55 \\
\hline Hersh & 1.33 \\
\hline Los Banos & 4.33 \\
\hline Nansene & 2.23 \\
\hline Portncuf & 1.22 \\
\hline Tifton & 0.901 \\
\hline Williams & 1.55 \\
\hline Woodward & 4.01 \\
\hline Zahl & 1.55 \\
\hline
\end{tabular}

"The correction factor $e$ is used in the equation: $c=d \times e$, where $c$ and $d$ are regression coeflicients identified in eqns. (2) and (5), respectively. 


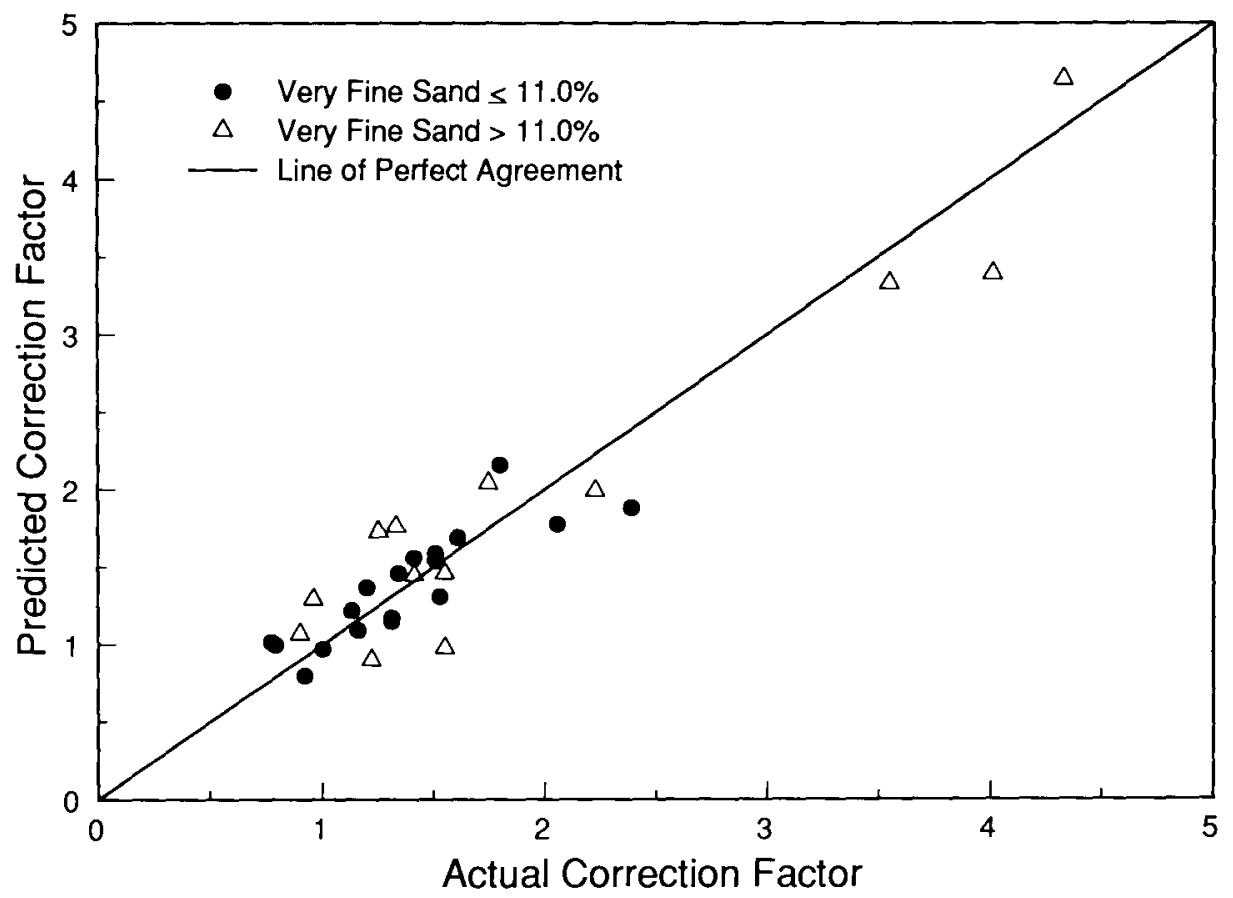

Fig. 9. Predieted vs actual correction factors for estimating rill sediment delivery rates under rainfall conditions.

Values of $e$ were calculated for each of the experimental sites using soil survey data and eqns. (7) and (8). Results of the analyses are shown in Fig. 9. Predicted vs. actual values of $e$ shown in Fig. 9 can be seen to be similar. Linear regression analyses were performed to compare predicted and actual values of $c$. Results of the statistical analysis are shown in Table 8. Equations

\section{TABLF 8}

Statistical analysis of predicted vs. actual correction factors

\begin{tabular}{|c|c|c|c|c|c|c|}
\hline \multirow[t]{2}{*}{ Regression equation } & \multirow{2}{*}{$\begin{array}{l}\text { Coeflicient of } \\
\text { determination } \\
\left(r^{2}\right)\end{array}$} & \multirow[t]{2}{*}{$F$} & \multicolumn{2}{|l|}{$\beta_{i}$} & \multicolumn{2}{|l|}{$\beta_{0}$} \\
\hline & & & Students $t$ & $\begin{array}{l}\text { Standard } \\
\text { error }\end{array}$ & Students 1 & $\begin{array}{l}\text { Standard } \\
\text { error }\end{array}$ \\
\hline \multicolumn{7}{|l|}{ Verv fine semd $\leqslant 11.0^{\circ}$} \\
\hline Predicted $=0.740$ actual +0.359 & 0.741 & 46 & -2.39 & 0.109 & 2.29 & 0.157 \\
\hline \multicolumn{7}{|l|}{ Verv fine sund $>11.00^{\prime \prime \prime}$} \\
\hline Predicted $=0.901$ actual +0.197 & 0.900 & 99 & -1.10 & 0.090 & 0.949 & 0.208 \\
\hline
\end{tabular}




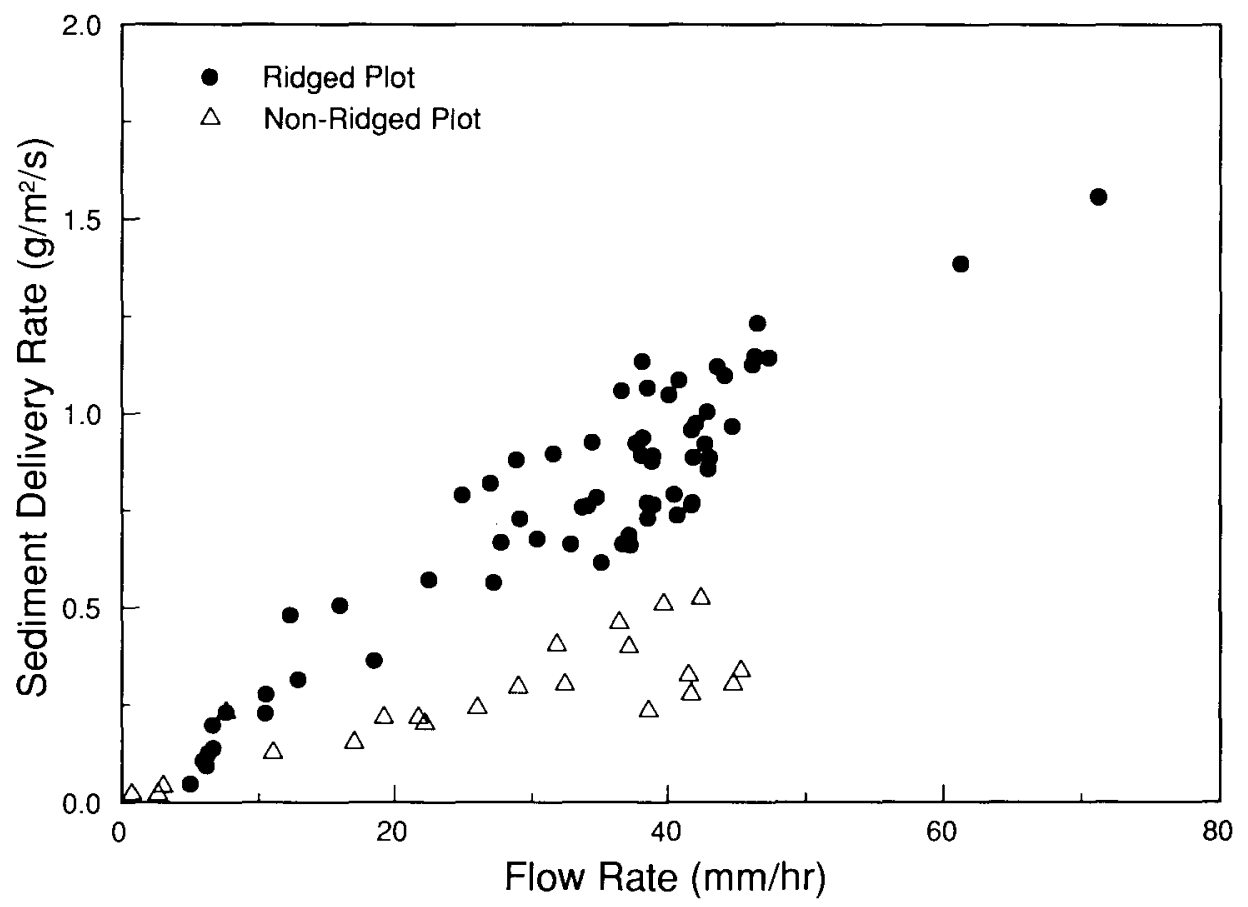

Fig. 10. Interrill sediment delivery rates vs. flow rates for a Nansene soil.

(7) and (8) produced coefficient of determination values of 0.741 and 0.900 , respectively.

The students $t$ test was used to evaluate the hypotheses that the regression coefficients shown in Table 8 equal 1 and the intercepts equal 0 at the $99 \%$ confidence level. The slopes were not significantly different from 1 nor were the intercepts significantly different from 0 . Thus, analyses of the experimental data suggests that eqns. (7) and (8) can be used to estimate the correction factor $e$.

INTERRILL SEDIMENT DELIVERY

Testing of interrill sediment delivery equation - ridged areas

Interrill sediment delivery rates vs. flow rates for the Nansene soil are shown in Fig. 10. Ridged and non-ridged plots were established on areas with slope gradients of approximately $60.0 \%$ and $7.1 \%$, respectively. Sediment delivery rates were much greater on the steeper surfaces. Owing to the wide variation in slope gradients and sediment delivery rates, separate analyses were performed for the ridged and non-ridged plots. 
The regression coefficient $b$ in eqn. (1) was first identified for each of the experimental soils, and a mean value of 1.0 (standard deviation equals 0.30 ) was then calculated for ridged areas. The following equation was obtained for interrill sediment delivery rate and flow rate given in grams per square meter per second and millimeters per hour, respectively, and slope given as a fraction sediment delivery rate from ridged areas $=f$ flow rate $\times$ slope $\mathrm{e}^{1.5}$

The appropriate regression coefficient $f$ in eqn. (9) was first determined for each of the experimental sites using non-linear regression procedures. Interrill sediment delivery rates were then estimated from eqn. (9). Finally, a simple linear regression of predicted vs. measured interrill sediment delivery rates was used to obtain appropriate $r^{2}$ values.

Results of the statistical analyses for ridged areas are shown in Table 9 . The regression coefficient $f$ was found to vary from 0.018 for the Heiden soil to 0.989 for the Pierre soil. Results of the regression analyses suggest that interrill sediment delivery rate from ridged areas can be estimated using flow rate and slope gradient. Predicted vs. measured interrill sediment delivery rates for the ridged Nansene soil are shown in Fig. 11. In general, close agreement was found between predicted and measured values.

\section{Parameter value identification - ridged areas}

Values of $f$ presented in Table 9 were related to soil properties shown in Table 2 using multiple regression analyses. The Pierre soil with its very large regression coefficient was not included in the analyses. The regression coefficient $f$ was highly correlated to magnesium content. For soils with magnesium content less than or equal to $1.6 \mathrm{cmol} \mathrm{kg}$ I

$$
\begin{aligned}
f= & -0.1677 \text { (aluminum) }+0.0016(\text { sand })+0.0023 \text { (silt) } \\
& +0.0019 \text { (very fine sand) }+0.0035 \text { (water-dispersible clay) }-0.1368
\end{aligned}
$$

where aluminum, sand, silt, very fine sand, and water-dispersible clay are given as percentages. All the regression coefficients shown in eqn. (10) were significantly different from 0 at the $95 \%$ confidence level. For soils with magnesium content greater than $1.6 \mathrm{cmol} \mathrm{kg}$

$$
\begin{aligned}
f= & +0.00069 \text { (calcium) }+0.00109 \text { (clay) }+0.00027 \text { (sand) } \\
& +0.00138 \text { (soil water content at } 0.3 \mathrm{MPa}) \\
& -0.00504 \text { (soil wwter content at } 1.5 \mathrm{MPa})+0.02122
\end{aligned}
$$

where calcium content is in centimol per kilogram, and clay, sand and soil 
TABLE 9

Coefficients used to estimate interrill sediment delivery rate from ridged areas given flow rate and slope gradient

Soil Regression coefficient

Coefficient of determination $\left(f^{\mathrm{at}}\right)$

$\left(r^{2}\right)$

Magnesium $\leqslant 1.6$ cmolkg

Academy

0.052

0.646

Amarillo

0.075

0.689

Caribou

0.025

0.626

Cecil

0.030

0.621

Collamer

0.047

0.603

Frederick

0.045

0.751

Grenada

0.041

0.931

Heiden

0.018

0.773

Hersh

0.070

0.769

Hiwassec

0.028

0.613

Miami

0.031

0.617

Opequon

0.044

0.628

Tifton

0.021

0.706

Whitney

0.070

0.646

Woodward

0.121

0.794

Magnesium $>1.6$ cmolkg

$\begin{array}{lll}\text { Barnes-MN } & 0.039 & 0.662 \\ \text { Barnes-ND } & 0.050 & 0.875 \\ \text { Gaston } & 0.029 & 0.610 \\ \text { Lewisburg } & 0.035 & 0.631 \\ \text { Los Banos } & 0.033 & 0.887 \\ \text { Manor } & 0.048 & 0.656 \\ \text { Mexico } & 0.051 & 0.880 \\ \text { Miamian } & 0.029 & 0.646 \\ \text { Nansene } & 0.049 & 0.870 \\ \text { Palouse } & 0.049 & 0.777 \\ \text { Pierre } & 0.989 & 0.806 \\ \text { Portneul } & 0.029 & 0.797 \\ \text { Sharpsburg } & 0.026 & 0.821 \\ \text { Sverdrup } & 0.044 & 0.825 \\ \text { Williams } & 0.050 & 0.766 \\ \text { Zahl } & 0.054 & 0.710\end{array}$

"Regression coefficient $f$ is used in the equation: interrill sediment delivery rate from ridged areas $=$ flow rate $\times$ slope ${ }^{1.5}$, where interrill sediment delivery rate and flow rate are in grams per square meter per second and millimeters per hour, respectively, and slope is given as a fraction. 


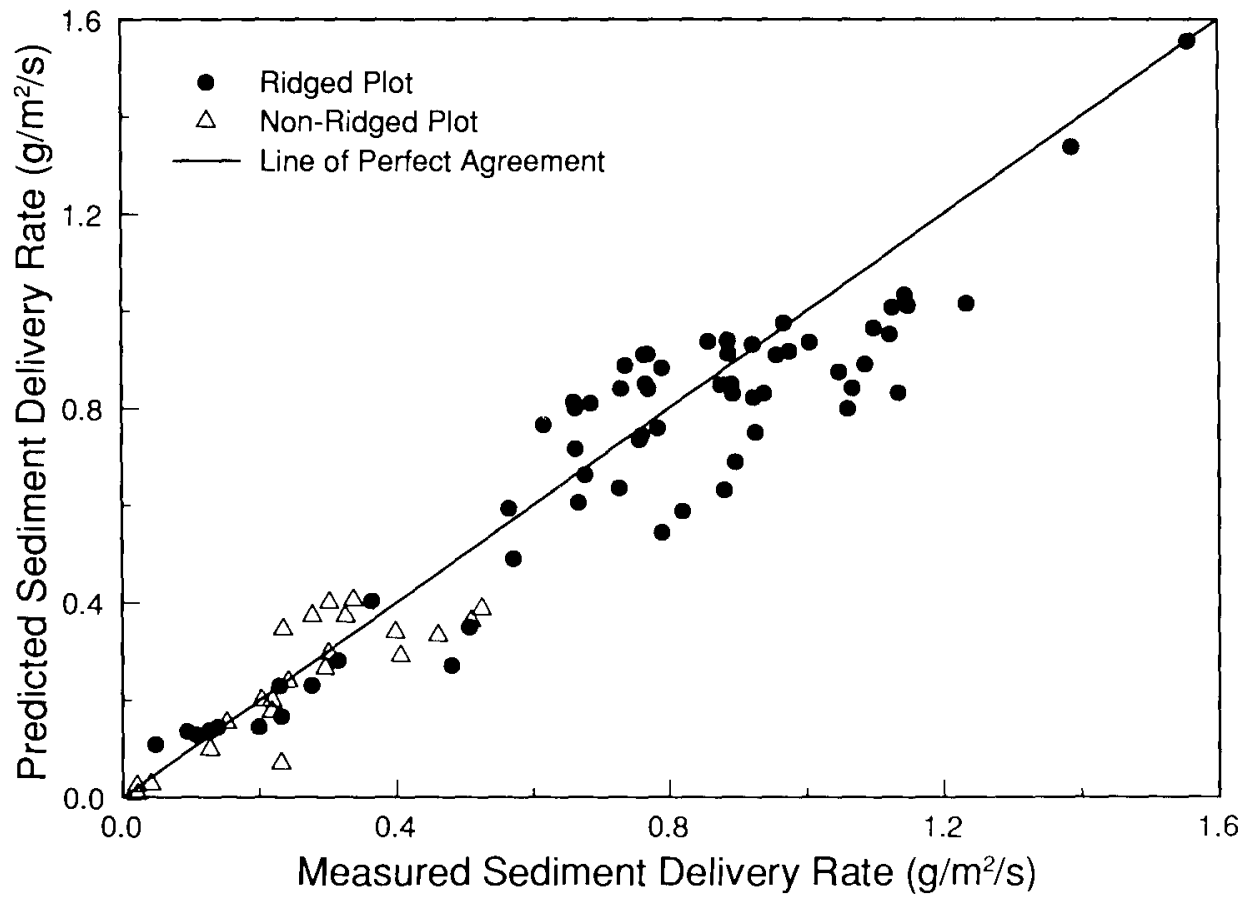

Fig. 11. Predicted vs. measured interrill sediment delivery rates for a Nansene soil.

water content at 0.3 and $1.5 \mathrm{MPa}$ are given as percentages. All the regression coefficients shown in eqn. (11) were significantly diflerent from 0 at the $90 \%$ confidence level. Soil survey data and eqns. (10) and (11) were used to estimate values of $f$ for each of the experimental soils. Results of the analyses are shown in Fig. 12. Predicted and actual values of $f$ shown in Fig. 12 were similar.

Linear regression analyses were also used to compare predicted and actual values of $f$. Results of the statistical analyses are shown in Table 10. Coefficient of determination values for eqns. (10) and (11) were found to be 0.860 and 0.850 , respectively. The students $/$ test was used to evaluate the hypotheses that the regression coefficients shown in Table 10 for ridged areas equal 1 and the intercepts equal 0 at the $95 \%$ confidence level. The slopes were not significantly different from I nor were the intercepts significantly different from 0 . Thus, analyses of the experimental data suggest that eqns. (10) and (11) can be used to estimate the regression coefficient $f$.

Testing of interrill sediment delivery equation-non-ridged areas

The regression coefficient $b$ in eqn. (1) was first identilied for each of the experimental soils, and a mean value of 1.0 (standard deviation equals 0.40 ) 


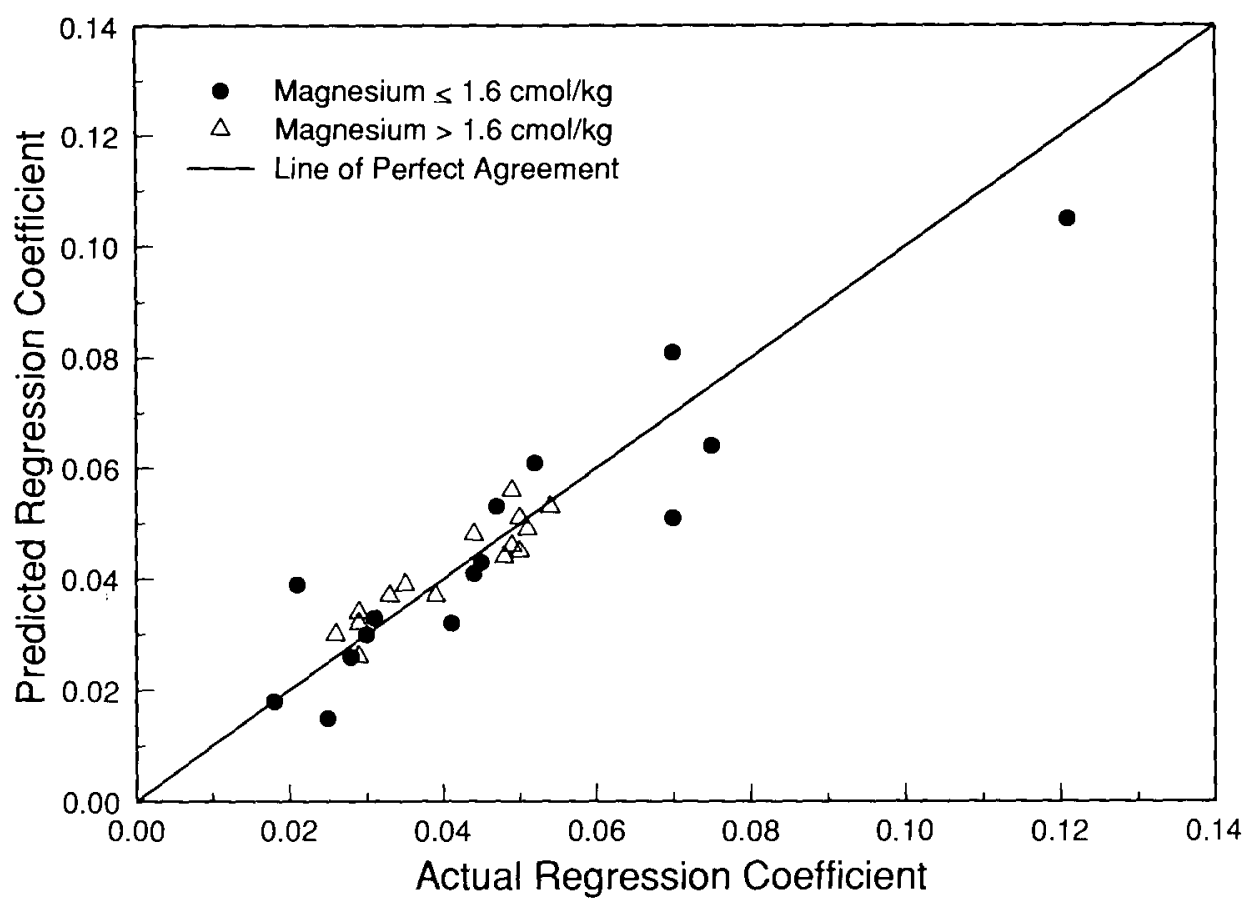

17ig. 12. Predicted vs actual regression coefficients for estimating interrill sediment delivery rates on ridged plots.

\section{TABI.E 10}

Statistical analysis of predicted vs. actual regression coefficients used to estimate interrill sediment delivery rate

\begin{tabular}{|c|c|c|c|c|c|c|}
\hline \multirow[t]{2}{*}{ Regression equation } & \multirow{2}{*}{$\begin{array}{l}\text { Coeflicient of } \\
\text { determination } \\
\left(r^{\prime}\right)\end{array}$} & \multirow[t]{2}{*}{$F$} & \multicolumn{2}{|l|}{$\beta_{1}$} & \multicolumn{2}{|l|}{$\beta_{0}$} \\
\hline & & & Students $t$ & $\begin{array}{l}\text { Standard } \\
\text { crror }\end{array}$ & Students $t$ & $\begin{array}{l}\text { Standard } \\
\text { error }\end{array}$ \\
\hline \multicolumn{6}{|l|}{ RIDGED AREAS } & Magnosium $\leqslant 1.6$ omolkg \\
\hline Predicted $=0.827$ actual +0.007 & 0.860 & 79 & 1.87 & 0.093 & 1.30 & 0.005 \\
\hline \multicolumn{7}{|l|}{ Magnesium > 1.6 cholkg' } \\
\hline Predicted $=0.837$ actual +0.007 & 0.850 & 74 & -1.68 & 0.097 & 1.83 & 0.004 \\
\hline \multicolumn{7}{|l|}{ NON-RIDGED AREAS } \\
\hline Predicted $=0.742$ actual +0.136 & 0.755 & 40 & -2.20 & 0.117 & 2.05 & 0.067 \\
\hline
\end{tabular}


TABLE 11

Coefficients used to estimate interrill sediment delivery rate from non-ridged areas given flow rate and slope gradient

\begin{tabular}{lll}
\hline Soil & $\begin{array}{l}\text { Regression coefficient } \\
\left(g^{*}\right)\end{array}$ & $\begin{array}{l}\text { Cocfficient of determination } \\
\left(r^{2}\right)\end{array}$ \\
\hline Academy & 0.665 & 0.719 \\
Amarillo & 1.09 & 0.846 \\
Barnes-MN & 0.317 & 0.763 \\
Barnes-ND & 0.365 & 0.886 \\
Heiden & 0.666 & 0.924 \\
Hersh & 0.441 & 0.640 \\
Nansene & 0.506 & 0.702 \\
Palouse & 0.739 & 0.873 \\
Portneuf & 0.249 & 0.969 \\
Sharpsburg & 0.634 & 0.929 \\
Sverdrup & 0.454 & 0.826 \\
Whitney & 0.279 & 0.721 \\
Williams & 0.697 & 0.954 \\
Woodward & 0.314 & 0.925 \\
Zahl & 0.471 & 0.817 \\
\hline
\end{tabular}

"Regression coefficient $g$ is used in the equation: interrill sediment delivery rate from non-

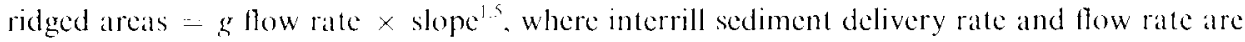
in grams per square meter per second and millimeters per hour, respectively, and slope is given ats a fraction.

was then cakulated for non-ridged areas. The following equation was obtained for estimating interrill sediment delivery on non-ridged areas sediment delivery rate from non-ridged areas $=g$ flow rate $\times$ slope $e^{1 .}$ where sediment delivery rate and flow rate are given in grams per square meter per second and millimeters per hour, respectively, and slope is given as a fraction.

Non-linear regression procedures were first used to identily the regression coefficient $g$. Equation (12) was then employed to estimate interrill sediment delivery. Finally, appropriate $r^{2}$ values were obtained from a simple linear regression of predicted vs. measured interrill sediment delivery rates.

Table 11 shows results of the statistical analyses for non-ridged areas. The regression coeflicient $g$ was found to vary from 0.249 for the Portneuf soil to 1.09 for the Amarillo soil. Results of the regression analyses suggest that flow rate and slope gradient can also be used to estimate interrill sediment delivery rate for non-ridged areas. Figure 11 includes predicted vs. measured interrill 
Gilley, Kincaid, Elliot \& Laflen in Journal of Hydrology 140 (1992)

sediment delivery rates for the non-ridged areas on the Nansene soil. In general, close agreement was found between predicted and measured values.

\section{Parameter value identification - non-ridged areas}

Multiple regression analyses were used to relate values of $g$ presented in Table 11 to soil properties shown in Table 2. Statistical analyses yielded the following equation

$$
\begin{aligned}
g= & 0.009 \text { (calcium) }+0.051 \text { (cation exchange capacity) } \\
& +16.2 \text { (coefficient of linear extensibility) }+1.75 \text { (sodium) } \\
& -0.184 \text { (soil water content at } 1.5 \mathrm{MPa})+0.624
\end{aligned}
$$

where calcium, cation exchange capacity and sodium are in centimol per kilogram, coefficient of linear extensibility is in centimeters per centimeter and soil water content at $1.5 \mathrm{MPa}$ is given as a percentage. All of the regression coefficients shown in eqn. (13) were significantly different from 0 at the $90 \%$ confidence level.

Values of $g$ were estimated for each of the experimental soils using soil survey data and eqn. (13). Results of the analyses are shown in Fig. 13. Predicted and actual values of $g$ shown in Fig. 13 were similar.

Predicted and actual values of $g$ were also compared using linear regression analyses. Results of the statistical analyses for the non-ridged areas are shown in Table 10. A coeflicient of determination value of 0.755 was found for eqn. (13).

The hypotheses that the regression coeflicient shown in Table 10 for nonridged areas equals 1 and the intercept equals 0 were evaluated using the students $/$ test. The slope was found to be not significantly different from 1 nor the intercept significantly diflerent from 0 at the $99 \%$ confidence level. Thus, analyses of the experimental data suggest that eqn. (13) can be used to estimate the regression coeflicient $g$.

\section{IIMITATIONS OF THE SFIIMINT DEIIVERY EQUATIONS}

Although the equations developed here appear to provide reasonable estimates of rill and interrill sediment delivery, in field situations there may be other factors that limit their application. For example, the experimental data used to parameterize the sediment delivery equations were obtained from sites where crop residues, vegetative materials and rock fragments were absent. Crop residue cover on rill and interrill areas could serve to protect these areas from soil detachment. If soils contain rock fragments, rill erosion may 


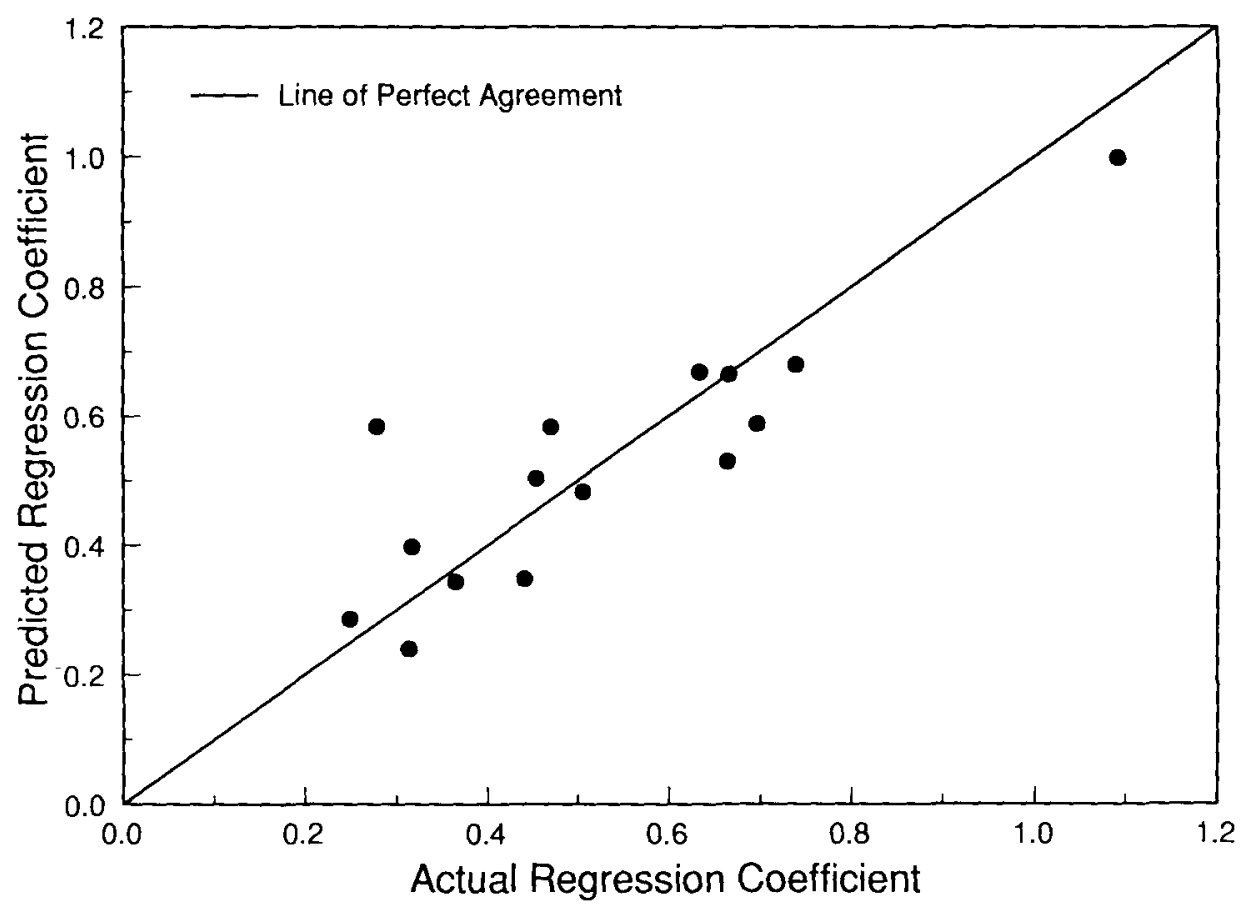

Fig. 13. Predicted vs. actual regression coefficients for estimating interrill sediment delivery rates on non-ridged plots.

decrease as channel armoring develops. Sediment delivery rates obtained using equations presented in this study may be substantially larger than values existing when crop residue or rock fragments are present.

Temporal variations in sediment delivery rates may also occur. These differences have been attributed to changes in soil cohesion, rainfall-induced soil consolidation and development of root fabric. Sediment delivery measurements used in this study were obtained immediately following tillage. At present, procedures for estimating temporal effects on sediment delivery have not been identified.

Flow rate and slope gradient are independent variables used in each of the sediment delivery equations. The range of measured flow rates on rill and interrill areas is shown in Table 3, while average rill and interrill slopes are presented in Table 1. The regression relationships which were derived in this study should only be used for flow rates and slope gradients within the range existing in the field experiments.

The data used to develop regression coefficients for estimating rill sediment delivery rates were obtained on relatively uniform slopes. These regression relationships may not provide reliable sediment delivery estimates at the 
bottom of steeply sloping concave slopes where substantial deposition is, occurring. Additional testing of the sediment delivery equations on areas with complex topography is needed.

The relatively large rill sediment delivery rates found for the without rainfall condition indicate substantial soil detachment by rill flow. Sediment delivery mechanisms would be radically different for a reach of rill where no erosion or deposition were occurring, but a substantial amount of sediment was supplied from lateral interrill flow. The regression equations derived in this investigation should only be applied to situations where the sediment delivery mechanisms are the same as those existing in the field experimental studies.

\section{SUMMARY AND CONCIUSIONS}

Empirical equations are often employed to represent complex erosion mechanisms. Flow rate and slope gradient have frequently been used as independent variables in relations employed to estimate sediment delivery for rivers, streams and irrigation furrows. In this study, equations which relate rill and interrill sediment delivery to a power function of flow rate and slope gradient were evaluated.

The sediment delivery equations were tested using data collected on soils located throughout the United States. The experimental sites were selected to cover a broad range of soil properties. Both rill and interrill sediment delivery estimates were provided by the equations.

A soil-related parameter value is used as a coeflicient in the sediment delivery equations. The parameter values were related to soil properties at the experimental sites using multiple regression analyses. Close agreement was found between predicted and actual regression coefficients.

Most rainfall simulators are difficult to fabricate and expensive to operate. As a result, sediment delivery data collected under rainfall conditions are limited. Regression equations were, therefore, identified for correcting rill sediment delivery measurements obtained without rainfall, to values expected under rainfall conditions.

Since the rill and interrill sediment delivery equations contain only flow rate and slope gradient as independent variables, they are relatively easy to use. The single parameter value found in the equations can be related to site-specific soil properties. Additional factors would need to be incorporated into the equations to obtain sediment delivery estimates from sites where crop residues, vegetative materials and rock fragments are present. 


\section{ACKNOWLEDGMENTS}

This paper is a contribution from USDA-ARS, in cooperation with the Agricultural Research Division, University of Nebraska, Lincoln, and is published as Journal Series No. 9739.

\section{REFERENCES}

Alonso, C. V., Neibling, W. H. and Foster, G. R., 1981. Estimating sediment transport capacity in watershed modeling. Trans. ASAE, 24(5): 1211-1220, 1226.

Elliot, W. J., Liebenow, A. M., Laflen, J. M. and KohI, K. D., 1989. A Compendium of Soil Erodibility Data from WEPP Cropland Soil Field Erodibility Experiments 1987 and 88. NSERL Report No. 3, USDA-ARS, West Lafayctte, IN, 317 pp.

Guy, B. T., Dickinson, W. T. and Rudra, R. P., 1987. The roles of rainfall and runoff in the sediment transport capacity of interrill flow. Trans. ASAE, 30(5): 1378-1386.

Julien, P. Y. and Simons, D. B., 1985. Sediment transport capacity of overland flow. Trans. ASAE, 28(3): 755-762.

Kemper, W. D., Trout, T. J., Brown, M. J. and Rosenau, R. C., 1985. Furrow erosion and water and soil management. Trans. ASAE, 28(5): 1564-1572.

Kirkby, M. J., 1978. Implications for sediment transport. In: M.J. Kirkby (Fditor), Hillslope Hydrology. John Wiley \& Sons, Chichester, pp. 325-363.

Lane, E. W., 1955. The importance of fluvial morphology in hydraulic engineering. Proc. An. Soc. Civ. Eng., 8I(745).

Quansah, C., 1985. Rate of soil detachment by overland flow, with and without rain, and its relationship with discharge, slope steepness and soil type. In: S.A. El Swaify, W.C. Moldenhauer and A. Lo (Editors), Soil Frosion and Conservation. Soil Conservation Society of America, Ankeny, IA.

Simons, D. B. and Senturk, F., 1976. Sediment Transport Technology. Water Resources Publication, Fort Collins, CO, 807 pp.

Soil Survey Staff, 1984. Procedures for collecting soil samples and methods of analysis for soil survey. USDA-SCS Soil Survey Investigations Report No. 1, U.S. Government Printing Office, Washington, DC.

Swanson, N. P., 1965. Rotating-boom rainfall simulator. Trans. ASAE, 8(1): $71-72$. 